\title{
IDENTIFICATION OF IRON OXIDES MINERALS IN WESTERN JAHAJPUR REGION, INDIA USING AVIRIS-NG HYPERSPECTRAL REMOTE SENSING
}

\author{
Himanshu Govil ${ }^{1}$, Mahesh Kumar Tripathi ${ }^{1, *}$, Prabhat Diwan ${ }^{1}$, Subhanil Guha $^{1}$, Monika ${ }^{1}$ \\ ${ }^{1}$ Department of Applied Geology, National Institute of Technology Raipur, India - tripathi.mahesh1@gmail.com
}

Commission V, SS: Natural Resources Management

KEYWORDS: AVIRIS-NG, Iron-oxide, Limonite, Western Jahajpur belt, Hyperspectral remote sensing.

\begin{abstract}
:
Hyperspectral remote sensing is being considered as an advanced technique for mineral identification of surficial deposits. In this research different iron oxides minerals such as limonite, goethite has been identified using AVIRIS-NG airborne hyperspectral remote sensing covering the Omkarpura, Itwa, and Chhabadiya mines area in Jahajpur Bhilwara, Rajasthan, India. AVIRIS-NG has shown robust performance in iron oxide identification in the study area. Mineral spectral signatures of the AVIRIS-NG data were compared with spectra of USGS spectral library, and field investigated mineral spectra of iron oxides and found very promising. The results allow us to conclude that due the high signal to noise ratios of the AVIRIS-NG, it is capable to identify the different iron bearing minerals in the visible and infrared portion of the electromagnetic spectrum.
\end{abstract}

\section{INTRODUCTION}

"The Airborne Visible-Infrared Imaging Spectrometer Next Generation (AVIRIS-NG) has been developed to provide continued access to high signal-to-noise ratio imaging spectroscopy measurements"(JPL NASA, 2015). Joint mission of ISRO-NASA has made an execution plan on February 04, 2016 to capture the surficial mineraldeposits in Jahajpur group belt of Bhilwara super group Rajasthan(SAC, 2016, JPL NASA, 2015). The surface mineralogy mapped and identify through characteristic absorption features which are located in the range of visible to shortwave-infrared range(Bell et al., 2010).The minerals which associated with $\mathrm{Fe}^{3+}$, $\mathrm{Al}-\mathrm{OH}$, $\mathrm{Mg}-\mathrm{OH}, \mathrm{CO}_{3}{ }^{2-}$, and $\mathrm{SO}_{4}{ }^{2-}$ can be mapped and discriminated by hyperspectral remote sensing data, smoothly (Clark et al., 1990, Crósta et al., 2003, Farooq and Govil, 2014, Jing et al., 2014, Clark, 1999, Eduardo et al., 2011). ${ }^{*}$ According to Parashar (2015) the hydrothermally developed hydroxyl minerals such as clay group of minerals and K-micas allow for remote identification which show the diagnostic absorption in infrared region(Parashar, 2015). The presence of mineral containing iron, such as goethite, jarosite, limonite and hematite due to erosion and weathering of hydrothermally developed sulphide deposits have various different absorptions in VNIR/SWIR regions(Parashar, 2015, Dhara, 1978).There are two major spectral intervals which is used for mineral identification and mapping in range of 0.4-2.5 $\mu \mathrm{m}$ of EMR spectrum. The $0.4-1.1 \mu \mathrm{m}$ of VNIR region are ubiquitous $\mathrm{Fe}^{2+}$ and $\mathrm{Fe}^{3+}$ have multispectral absorptions related to electronic transitions. The $\mathrm{Fe}^{2+}, \mathrm{Fe}^{3+}$ have shown charge-transfer absorptions are at around $0.6 \mu \mathrm{m}$ band width. There are various distinct electronic absorption features near $0.6 \mu \mathrm{m}$ and $0.9 \mu \mathrm{m}$ by Limonite and Goethite (Roberto and Filho, 2000). The $\mathrm{Fe}^{3+}$ have shown

${ }^{*}$ Corresponding author absorption at $0.43,0.5$ and $0.6 \mu \mathrm{m}$, and $\mathrm{Fe}^{2+}$ have shown absorption features in $0.9-1.2 \mu \mathrm{m}$ (Magendran and Sanjeevi, 2014, Murphy and Monteiro, 2013, Govil et al., 2018, Cloutisa et al., 2006, Bell et al., 2010, Pour and Hashim, 2015).

\section{GEOLOGICAL SETTINGS OF THE STUDY AREA}

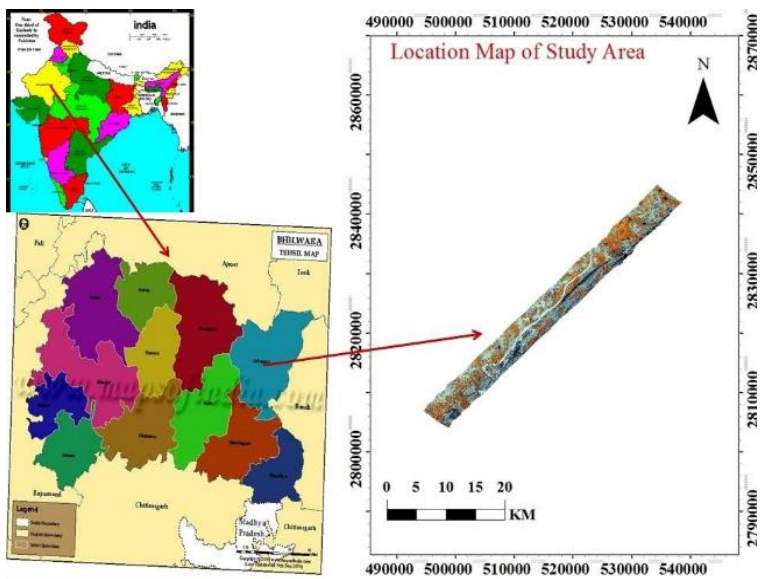

Figure 1. Location map of the study area

The basement rock of Jahajpur group of Bhilwara supergroup are archaean age. There are two parallel ridges of dolomitic limestone and quartzite striking in north east direction along and across the Banas river. The quaternary sediments are exposed in the river channels. The western part of Jahajpur group is intruded with Mangalwar complex and in east surrounded by Hindoli groups of rocks. There are four types of rocks are reported by various scientist and researchers such as dolomite, phyllite, quartzites, banded iron formation (BIF), and quaternary sediments. The identified minerals which is reported by geological society 
of India are iron, clay, talc, and soapstone(Geological Survey of India-District Report., 1977, Sinha-Roy, 1984, Sinha Roy and Malhotra, 1988, Sinha-Roy, 2001, Saxena and Pandit, 2012, Heron, 1935, Srivastava, 1968, Yadav et al., 2001, Shekhawat and Sharma, 2001) .

\section{DATA AND METHODOLGY}

The acquired date of AVIRIS NG hyperspectral image is 04/02/2016 for Jahajpur region of Bhilwara district Rajasthan. AVIRIS-NG have 427 contiguous channels with $5 \mathrm{~nm}$ and 8.1 spectral and spatial resolution respectively in spectrum region $0.3-2.551 \mu \mathrm{m}$ of EMR(Hamlin et al., 2011, JPL NASA, 2015, SAC, 2016). The concepts and instruments of AVIRIS-NG are completely free from keystone and smile error distortions. The AVIRIS-NG data have highest signal to noise ratio. The adopted approach of methodology is that preprocessing and determination of AVIRIS-NG airborne hyperspectral data, Image calibration, atmospheric correction, bad band removal, and dark subtraction method related to preprocessing of image, and extraction spectral features are related to determination process of approach. The extracted mineral spectra are correlated and compared with USGS spectral library, and field spectra(King and Clark, 2000). Minerals are identified through absorption and reflectance in a particular bandwidth for particular minerals through interpretation(Molan et al., 2014) and compared with mineral spectral library of USGS..

\begin{tabular}{|c|c|c|c|}
\hline $\begin{array}{l}\text { Sensor } \\
\text { Altitude }\end{array}$ & $4-8 \mathrm{~km}$ & $\begin{array}{l}\text { Spectral } \\
\text { Range }\end{array}$ & $\begin{array}{ll}380 \mathrm{~nm} & \text { to } \\
2510 \mathrm{~nm} & \\
\end{array}$ \\
\hline $\begin{array}{l}\text { Spatial } \\
\text { Resolution }\end{array}$ & $8.1 \mathrm{~m}$ & $\begin{array}{l}\text { Spectral } \\
\text { Coverage }\end{array}$ & Continuous \\
\hline $\begin{array}{l}\text { Swath } \\
\text { Width }\end{array}$ & $4-6 \mathrm{~km}$ & $\begin{array}{l}\text { Spectral } \\
\text { Resolution }\end{array}$ & $\begin{array}{lll}5 \mathrm{~nm} & \pm 0.5 \\
\mathrm{~nm} & & \\
\end{array}$ \\
\hline $\begin{array}{l}\text { VNIR } \\
\text { Range }\end{array}$ & $\begin{array}{l}400 \mathrm{~nm}- \\
1000 \mathrm{~nm}\end{array}$ & SWIR range & $\begin{array}{l}900 \mathrm{~nm}- \\
2500 \mathrm{~nm}\end{array}$ \\
\hline $\begin{array}{l}\text { IFOV } \\
(\mathrm{mrad})\end{array}$ & $1.0 \mathrm{mrad}$ & $\begin{array}{l}\text { Total } \\
\text { number of } \\
\text { bands }\end{array}$ & 425 \\
\hline
\end{tabular}

Table 1. The specified parameters of AVIRIS-NG (Hamlin et al., 2011, Bhattacharya, 2016, JPL NASA, 2015)

\section{RESULT AND DISCUSSION}

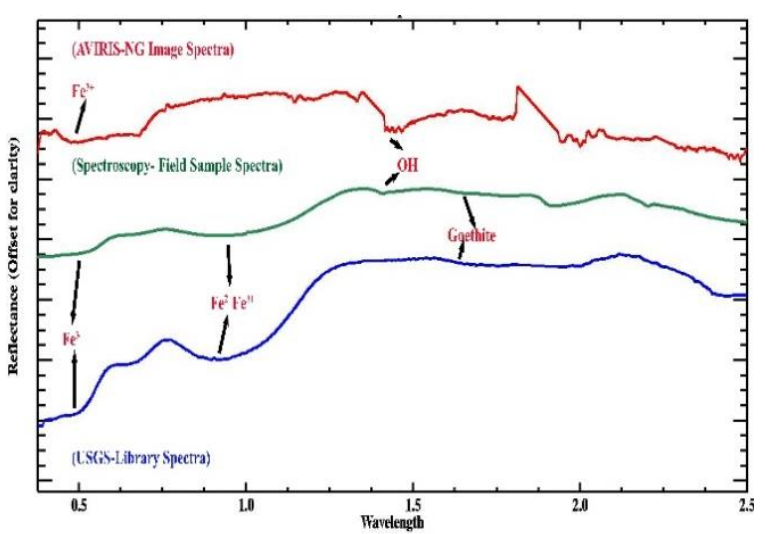

Figure 2:Spectral features of goethite minerals.

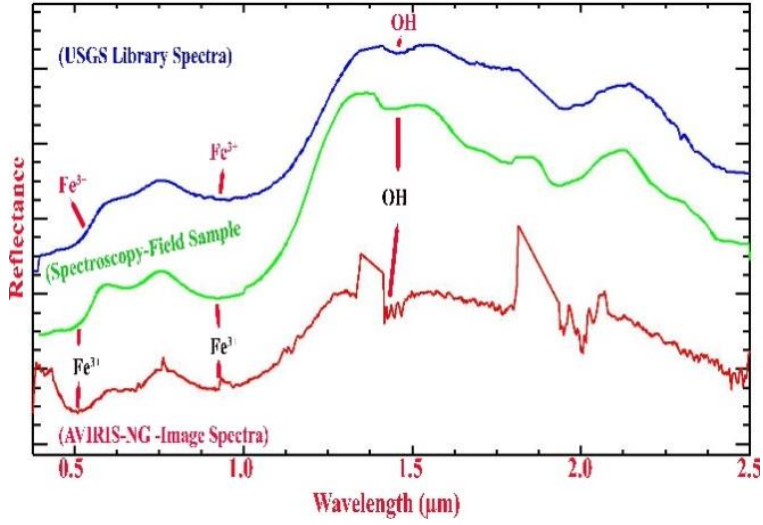

Figure 3: Spectral features of goethite/limonite minerals

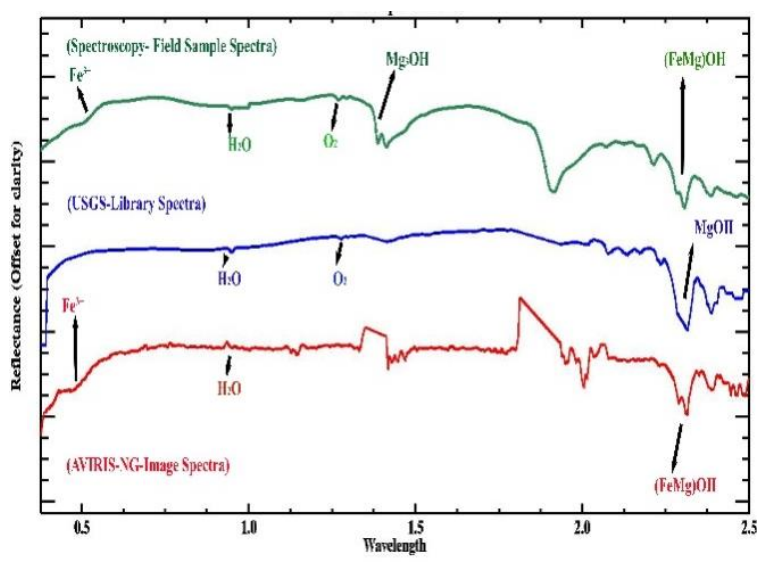

Figure 4: Spectral features talc minerals and associated goethite minerals

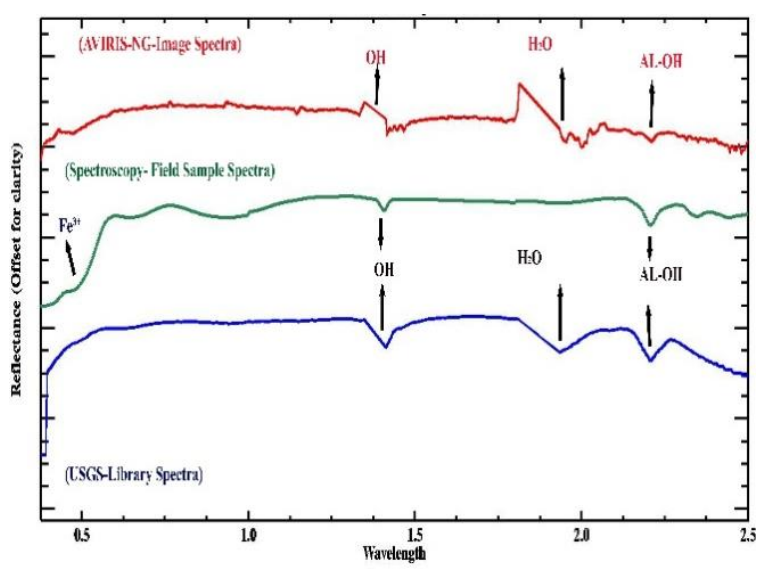

Figure 5: Spectral features of montmorillonite and goethite /limonite 


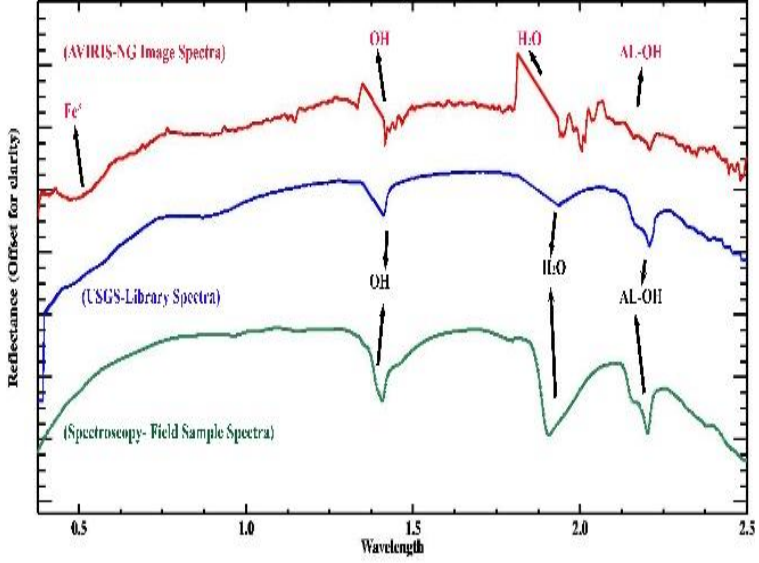

Figure 3: Spectral features of kaosmec and goethite minerals

The hydrothermal alteration product limonite $\left(\mathrm{Fe}^{+3 \mathrm{O}}(\mathrm{OH})\right.$. $\mathrm{nH}_{2} \mathrm{O}$ ) iron oxide minerals are identified in dolomitic rocks, near Itwa/Omkarpura village (Figure 2 and 3) andnear Ghevaria talc mines (Figure 4), Chhabadiya village (Figure 5), Omkarpura village (Figure 6) of Jahajpur, Bhilwara, Rajasthan. The image spectra of limonite at location Itwa and Omkarpura, showing distinct absorption features at bandwidth of image spectra such as at $0.5417,0.9274 \mu \mathrm{m}$ with presence of $\mathrm{OH}$ absorptions at 1.331-1.4182 $\mu \mathrm{m}$ and 1.8080-1.934 $\mu \mathrm{m}$, but at location Chhabadiya and Ghevaria iron oxides are present as minor content as impurity in clay and talc minerals.There is similarity between field measured spectra of limonite, USGS mineral spectral library, and image spectra. Field measured spectra have shown absorptions at $0.5070 \mu \mathrm{m}, 0.6260 \mu \mathrm{m}, 0.9310 \mu \mathrm{m}$, $1.4132 \mu \mathrm{m}, 1.8080 \mu \mathrm{m}$.(Magendran and Sanjeevi, 2014, Murphy and Monteiro, 2013, Mielke et al., 2016, Roberto and Filho, 2000, Govil et al., 2018, Pour and Hashim, 2014, Pour and Hashim, 2015, Zhang et al., 2016, Boesche et al., 2015).

\section{CONCLUSION}

The interpretation and identification of iron oxides/hydroxide(Highway, 1991) minerals Limonite/Goethite measured through field spectra using spectroradiometer, and image spectra of AVIRIS-NG and compared with USGS mineral spectral library, which have shown absorptions at 0.46, 0.54 (Grebby et al., 2014) 0.76, 0.92 (Pour and Hashim, 2014), 2.0, 2.2, 2.35 and $2.39 \mu \mathrm{m}$ in VNIR-SWIR indicates association of oxides/hydroxides, clay, talc, and carbonate minerals. This result shows that the AVIRIS-NG data have robust performance and capability in mapping and identification of the alteration zones because association of these mineralsare indicating phyllic, argillic (Lagat, 2009, Zhang et al., 2016) and supergene product of gossan(Ramakrishnan and Bharti, 1996) and alteration of oxidation and reduction, and weathering environment. The conclusion is that AVIRISNG have better capability to differentiate and identify the oxides minerals and facies alteration.

\section{ACKNOWLEDGEMENTS}

This work is supported by Space Application Center, Indian Space Research Organization India grant EPSA/4.2/2017.

\section{REFERENCES}

Bell, J. H., Bowen, B. B. and Martini, B. A. (2010) 'Imaging spectroscopy of jarosite cement in the Jurassic Navajo Sandstone', Remote Sensing of Environment. Elsevier Inc., 114(10), pp. 2259-2270. doi: 10.1016/j.rse.2010.05.002.

Bhattacharya, B. K. (2016) 'AVIRIS Programme and Science Plan’, (February), pp. 18-22.

Boesche, N. K. et al. (2015) 'Hyperspectral REE (rare earth element) mapping of outcrops-applications for neodymium detection', Remote Sensing, 7(5). doi: 10.3390/rs70505160.

Clark, R.N. et al. (1990) 'High spectral resolution reflectance spectroscopy of minerals.', J. Geophys. Res., 95 , pp. 12653-12680.

Clark, R. N. (1999) Spectroscopy of Rocks and Minerals, and Principles of Spectroscopy.

Cloutisa, Edward A., et al., . (2006) 'Detection and discrimination of sulfate minerals using reflectance spectroscopy.', Icarus, 184(1), pp. 121-157.

Crósta, A.P. et al. (2003) 'Targeting key alteration minerals in epithermal deposits in Patagonia, Argentina, using ASTER imagery and principal component analysis.' Int. J. Remote Sens., 24, pp. 4233-4240.

Dhara, M. K. (1978) Geological survey of India report on exploration of lead-zinc deposits in the Tiranga hill block, Pur banera belt, Bhilwara district, Rajasthan, (Field Season 1974-75 and 1975-76).

Eduardo, L., Roberto, C. and Filho, D. S. (2011) 'Identi fi cation of mineral components in tropical soils using re $\mathrm{fl}$ ectance spectroscopy and advanced spaceborne thermal emission and re fl ection radiometer ( ASTER ) data', Remote Sensing of Environment. Elsevier Inc., 115(8), pp. 1824-1836. doi: 10.1016/j.rse.2011.02.023.

Farooq, S. and Govil, H. (2014) 'Mapping Regolith and Gossan for Mineral Exploration in the Eastern Kumaon Himalaya, India using hyperion data and object oriented image classification', Advances in Space Research, 53(12). doi: 10.1016/j.asr.2013.04.002.

Geological Survey of India-District Report. (1977) Geology and minerals resources of Bhilwar district. 
Govil, H. et al. (2018) 'Identi fi cation of new base metal mineralization in Kumaon Himalaya , India , using hyperspectral remote sensing and hydrothermal alteration', Ore Geology Reviews. Elsevier, 92(September 2017), pp. 271-283. doi: 10.1016/j.oregeorev.2017.11.023.

Grebby, S. et al. (2014) 'The Impact of Vegetation on Lithological Mapping Using Airborne Multispectral Data: A Case Study for the North Troodos Region, Cyprus', pp. 10860-10887. doi: 10.3390/rs61110860.

Hamlin, L. et al. (2011) 'Imaging spectrometer science measurements for terrestrial ecology: AVIRIS and new developments', IEEE Aerospace Conference Proceedings, (August). doi: 10.1109/AERO.2011.5747395.

Heron, A. . (1935) 'Heron, A.M (1935) Synopsis of the pre-Vindhyan Geology of Rajputana.', Trans. Nat. Instt. Sci. India., I, pp. 17-33.

Highway, F. (1991) 'Rock and Mineral Identification for Engineers', (November).

Jing, C. et al. (2014) 'Regional-scale mineral mapping using ASTER VNIR / SWIR data and validation of reflectance and mineral map products using airborne hyperspectral CASI / SASI data', International Journal of Applied Earth Observations and Geoinformation. Elsevier B.V., 33, pp. 127-141. doi: 10.1016/j.jag.2014.04.014.

JPL NASA (2015) ISRO - NASA AVIRIS - NG Airborne Flights over India Sciene Plan Document for Hyperspectral Remote Sensing.

King, T. V. V. and Clark, R. N. (2000) 'Verification of remotely sensed data.', In: Kuehn, F., King, T., Hoerig, B., Pieters, D. (Eds.), Remote Sensing for Site Characterization. Springer, Berlin, pp. 59-61.

Lagat, J. (2009) 'Hydrothermal alterartion mineralogy in geothermal fields with case example from Olkaria domes geothermal fields, Kenya', pp. 1-24.

Magendran, T. and Sanjeevi, S. (2014) 'Hyperion image analysis and linear spectral unmixing to evaluate the grades of iron ores in parts of Noamundi , Eastern India', International Journal of Applied Earth Observations and Geoinformation. Elsevier B.V., 26, pp. 413-426. doi: 10.1016/j.jag.2013.09.004.

Mielke, C. et al. (2016) 'EnGeoMAP 2.0-Automated Hyperspectral Mineral Identification for the German EnMAP Space Mission', Remote Sensing. Multidisciplinary Digital Publishing Institute, 8(2), p. 127. doi: $10.3390 /$ rs 8020127 .

Molan, Y. E., Refahi, D. and Tarashti, A. H. (2014)

'Mineral mapping in the Maherabad area, eastern Iran, using the hyMap remote sensing data', International Journal of Applied Earth Observation and Geoinformation, 27(PARTB). doi: 10.1016/j.jag.2013.09.014.

Murphy, R. J. and Monteiro, S. T. (2013) 'Mapping the distribution of ferric iron minerals on a vertical mine face using derivative analysis of hyperspectral imagery (430970nm)', ISPRS Journal of Photogrammetry and Remote Sensing. International Society for Photogrammetry and Remote Sensing, Inc. (ISPRS), 75, pp. 29-39. doi: 10.1016/j.isprsjprs.2012.09.014.

Parashar, C. (2015) Mapping of Alteration mineral zones by combining techniques of Remote Sensing and Spectroscopy in the parts of SE- Rajasthan. Andhra University.

Pour, A. B. and Hashim, M. (2014) 'Exploration of gold mineralization in a tropical region using Earth Observing-1 ( EO1 ) and JERS-1 SAR data : a case study from Bau gold field, Sarawak, Malaysia', 1, pp. 2393-2406. doi: 10.1007/s12517-013-0969-3.

Pour, A. B. and Hashim, M. (2015) 'Hydrothermal alteration mapping from Landsat-8 data, Sar Cheshmeh copper mining district, south-eastern Islamic Republic of Iran', Journal of Taibah University for Science. Taibah University, 9(2), pp. 155-166. doi:

10.1016/j.jtusci.2014.11.008.

Ramakrishnan, D. and Bharti, R. (1996) 'Hyperspectral Remote Sensing and Applications', CURRENT SCIENCE, 108(v. 2821), pp. 879-891. Available at: https://books.google.co.uk/books?id=N-tOAAAAMAAJ.

Roberto, C. and Filho, D. E. S. (2000) 'Hyperspectral remote sensig for mineral mapping: A case study at: A case -study at Alto Paraiso de Goias, Central Brazil.', Revista Brasileira de Geociências, 30(3), pp. 551-554.

SAC, I. (2016) 'Space Application Center.pdf', SAC COURIER, 41(3). Available at:

http://www.sac.gov.in/SACSITE/SAC

Courier/July2016.pdf.

Saxena, A. S. H. A. and Pandit, M. K. (2012)

'Geochemistry of Hindoli Group Metasediments, SE

Aravalli Craton, NW India: Implications for

Palaeoweathering and Provenance', Journal geological society of India, 79(March), pp. 267-278. Available at: http://mecl.gov.in/Reports/EXE_SUMM_BANERA.pdf.

Shekhawat, L. S. and Sharma, V. (2001) Basemetal exploration in Pachanpura-Chhabbriya block, UmedpuraManoharpura block,Gelaji (East) and Amargarh blocks, Jahajpur belt, Bhilwara district, Rajasthan (Final Report For The Field Seasons 1999-2000 \& 2000-2001).

Sinha-Roy, S. (1984) 'Precambrian folded unconformity in Rajasthan.pdf’, CURRENT SCIENCE, 53(22), pp. 12051207

Sinha-Roy, S. (2001) 'Neotectonically controlled catchment capture: An example from the Banas and Chambal drainage basins, Rajasthan', Current Science, 80(2), pp. 293-298. 
Sinha Roy, S and Malhotra, G. (1988) 'Structural relations of Proterozoic cover and its basement: An example from the Jahazpur belt, Rajasthan.', Jour. Geol. Sec. India (in press).

Srivastava, R. P. (1968) Geological survey of Indiasystmatic geological mapping in parts of Ajmer,Bhilwara and Udaipur districts, Rajsthan included in topo-sheet nos. 45 K/1 \& 5. (Progress Report for the field-season 1966$67)$.

Yadav, O. P. et al. (2001) 'Short communications and its significance in west Jahajpur basin, Bhilwara district, Rajsthan', Journal geological society of India, 58(DEC), pp. $0-3$.

Zhang, T. et al. (2016) 'Integrating data of ASTER and Landsat-8 OLI (AO) for hydrothermal alteration mineral mapping in duolong porphyry cu-au deposit, Tibetan Plateau, China', Remote Sensing, 8(11). doi: $10.3390 /$ rs 8110890 . 